\title{
Sistem Informasi Persediaan Barang pada CV. Anak Teladan
}

\author{
Fenny Hidha Rahmawati ${ }^{1}$, Esthi Adityarini ${ }^{2}$
}

\begin{abstract}
CV. Anak Teladan is a company engaged in the distribution of books, and supporting tools for kindergartens. As for the problems that occur in the current system that is for processing data on incoming goods, data on outgoing goods and stock of goods is still recorded in paper or book in accordance with receipts and travel documents from suppliers that contain several many incoming and outgoing goods to be sent to the customer. Data collection of inventory items is only recorded on a piece of paper and then copied back into the next book the office section that will copy into the computer, sometimes has difficulty in getting stock information, so the information provided is often not in accordance with the availability of the available items. The purpose of this study is to create a system of inventory information, which can manage incoming and outgoing goods and stock items. The information system that has been produced by this design can manage data entry and exit goods, inventory data.
\end{abstract}

Intisari - CV. Anak Teladan merupakan perusahaan yang bergerak dibidiang distributor buku, dan alat penunjang untuk Taman Kanak-kanak. Adapun masalah yang terjadi pada sistem yang telah berjalan saat ini yaitu untuk pengolahan data barang masuk, data barang keluar dan stok barang masih di catat ke dalam kertas atau buku sesuai dengan kwitansi dan surat jalan dari supplier yang berisi beberapa banyak barang masuk dan keluar untuk dikirim ke pelanggan. Pendataan persediaan stok barang hanya dicatat di selembar kertas kemudian di salin kembali ke dalam buku berikutnya bagian kantor yang akan menyalin ke dalam komputer, terkadang mengalami kesulitan dalam mendapatkan informasi stok barang, sehingga informasi yang diberikan sering tidak sesuai dengan kertersediaan barang yang ada. Tujuan penelitian ini adalah membuat sistem informasi persedian barang, yang dapat mengelola barang masuk dan keluar serta stok barang. Sistem informasi yang telah dihasilkan perancangan ini dapat mengelola data barang masuk dan keluar, serta data stok barang.

Kata Kunci - Barang Masuk, Barang Keluar, Sistem Informasi, Persediaan Barang.

\section{PENDAHULUAN}

Seiring berkembangnya kemajuan teknologi informasi dan komunikasi, persaingan bisnis dalam dunia industri semakin ketat. Perusahaan semakin banyak yang terus melakukan usaha dan strategi dalam mempertahankan bisnisnya. Kesuksesan perusahaan dalam mempertahankan bisnisnya

\footnotetext{
${ }^{1}$ Program Studi Sistem Informasi STMIK STMIK Antar Bangsa, Jl. HOS Cokroaminoto Kawasan Bisnis CBD Ciledug , Blok A5, No.29-36, Karang Tengah, Kota Tangerang; Telp. (021) 5098-6099; e-mail: fennyhida910@ gmail.com

${ }^{2}$ Program Studi Manajemen Bisnis Syariah Universitas Daarul Qur'an, Jl. Cipondoh Makmur Raya Rt.003/Rw.09, Cipondoh, Kota Tangerang Telp. (021) 5098-6099; e-mail: esthi.aditya@gmail.com
}

tidak terlepas dari peran perusahaan tersebut dalam mengelola inventory (persediaan) barang sehingga dapat memenuhi permintaan dari pelanggan dengan semaksimal mungkin.

$\mathrm{CV}$. Anak Teladan merupakan sebuah perusahaan yang bergerak di bidang distributor buku belajar taman kanakkanak dan alat penunjang sekolah, yang dijual dengan harga murah sehingga banyak pelanggan ataupun agen dari setiap daerah yang membeli barang pada CV. Anak Teladan.

CV. Anak Teladan selalu melakukan pengawasan dan pencatatan terhadap persediaan barang. Selama ini untuk data pengolahan persediaan barang masih dilakukan secara manual, seperti pendataan barang masuk dan keluar serta untuk pendataan stok barang hanya dicatat di selembar kertas atau katalog penjualan.

Sistem komputerisasi sangat diperlukan untuk menunjang kegiatan sehingga pencatatan yang diakukan lebih efektif dan efisien serta informasi yang dihasilkan lebih tepat dan akurat. Pada kegiatan inventaris nya, admin bagian kantor masih menggunakan Microsoft Excel, yang tidak mempunyai Database Management System (DBMS). Dimana Microsoft Excel ini masih belum dapat digunakan untuk membuat aplikasi database dengan cepat karena belum dilengkapi dengan fasilitas-fasilitas yang lengkap dan mudah digunakan seperti penggunaan tombol-tombol secara otomatis, data tidak dapat di input secara otomatis dan pembuatan laporan tidak dapat dilakukan secara otomatis. Sehingga dari permasalahan tersebut terkadang terjadi kesalahan dalam perhitungan stok barang, kesulitan dalam pencatatan dan pembuatan laporan barang masuk dan barang keluar setiap bulannya.

Tujuan dari penelitian ini adalah membuat sistem informasi yang dapat membantu staf gudang dalam mengelola dan mendata barang masuk dan keluar selain itu dapat melakukan pengontrolan stok barang yang ada di gudang sehingga dapat memberitahukan jumlah stok barang dengan cepat dan akurat dan menyajikan pemrosesan data barang yang masuk dan keluar. Untuk memudahkan dalam penelitian ini, maka penulis membatasi permasalahan hanya membahas tentang informasi persediaan barang, jumlah stok barang serta informasi masuk dan keluarnya barang. Penulis menggunakan bahasa pemrograman PHP dan database yang digunakan adalah MySql.

Penelitian sebalumnya yang penulis jadikan sebagai rujukan adalah penelitian yang berjudul "Sistem Informasi Persediaan, Pembelian dan Penjualan Barang Pada CV. Evee Store Cileungsi" penelitian ini membuat sistem informasi yang memanfaatkan kemajuan Teknologi komputer yaitu, dengan membuat sistem informasi yang terkomputerisasi sehingga data yang di kelola dapat terintegrasi dengan baik [4].

Selain penelitian diatas adalah penelitian yang berjudul 
"Rancang Bangun Sistem Informasi Persediaan Barang Berbasis Web dengan metode FAST (Framework For The Aplications)". Penelitian ini bertujuan untuk membangun sistem informasi berbasis web sebagai solusi permasalahan yang timbul dari pengolahan data secara manual. Dengan merubah sistem menjadi terkomputerisasi, maka diharapkan pengelolaan persediaan barang dapat menjadi lebih efektif dan efisien, penyajian laporan persediaan barang menjadi lebih akurat dan tepat waktu [5].

\section{TINJAUAN PUSTAKA}

\section{A. Pengertian sistem}

Sistem adalah sekumpulan elemen yang saling berkaitan atau terpadu yang dimaksudkan untuk mencapai suatu tujuan [1].

\section{B. Karakteristik sistem}

Sebuah sistem memiliki karakteristik atau sifat-sifat tertentu, yang mencirikan hal tersebut bisa dikatakan sebagai suatu sistem. Karakteristik sistem yang dimaksud adalah Komponen Sistem (Components), Batasan Sistem (Boundary), Lingkungan Luar Biasa (Environtment), Penghubung Sistem (Interface), Masukan Sistem (Input), Keluaran Sistem (Output), Pengolah Sistem (Procces), Sasaran Sistem (Objective) [2].

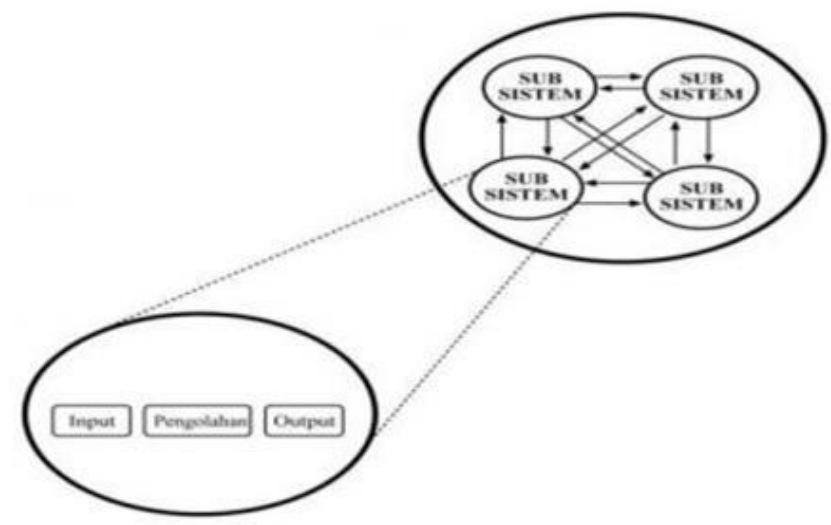

Sumber : Sutabri [2]

Gbr 1 Karakteristik Sistem

\section{Pengertian Informasi}

Informasi sebagai data yang telah diproses sedemikian rupa sehingga dapat meningkatkan pengetahuan seseorang yang menggunakan data tersebut [1]. Informasi memiliki siklus yang menggambarkan pengolahan data menjadi informasi dan pemakaian informasi untuk mengambil keputusan, hingga akhirnya dari tindakan hasil pengambilan keputusan tersebut dihasilkan data kembali [1] .

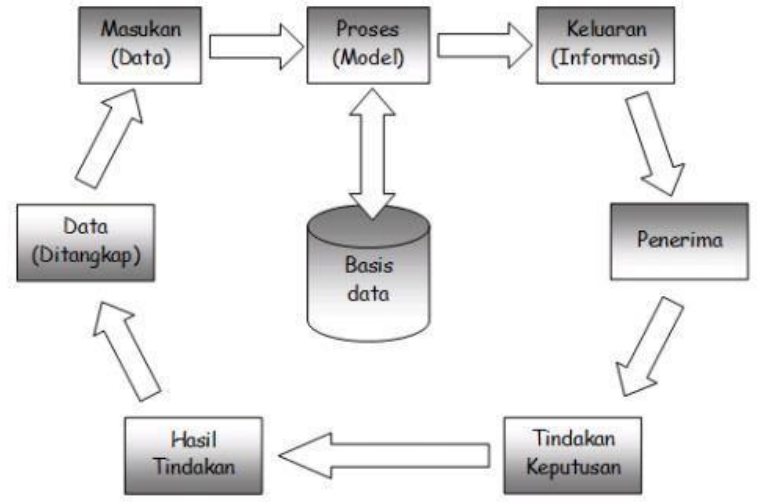

Sumber : Kadir [1]

Gbr 2 Siklus Informasi

D. Pengertian Persediaan Barang

Persediaan merupakan aset atau aktiva lancar yang dimiliki perusahaan yang biasanya melakukan kegiatan bisnis dengan menjual barang dagangan atau barang hasil produksinya [1].

Adapun yang merupakan jenis-jenis persediaan yaitu:

1) Bahan Baku Penolong

Bahan baku merupakan barang-barang yang dapat menjadi bagian dari produk jadi yang dengan mudah dan dapat diikuti biayanya. Sedangkan bahan baku penolong merupakan barang-barang yang juga dapat menjadi bagian dari produk jadi namun jumlahnya relatif kecil atau sulit diikuti biayanya. Misalnya dalam suatu perusahaan mabel, bahan baku kayu, rotan besi, siku, bahan penolong adalah paku dan dempul.

2) Supplier Pabrik

Barang -barang yang dapat mempunyai fungsi melancarkan proses produksi misalnya oli mesin, bahan pembersih mesin.

3) Barang Dalam Proses

Barang yang sedang dikerjakan. Untuk dapat dijual diperlukan pengerjaan lebih lanjut.

4) Produk Selesai

Yaitu barang-barang yang sudah selesai dikerjakan dalam proses produksi dan menunggu saat penjualannya [7].

\section{E. Pengujian Kotak Hitam (Black-Box Testing)}

Menguji perangkat lunak dari segi spesifikasi fungsional tanpa menguji desain atau kode program. Pengujian dimaksudkan utntuk mengetahui apakah fungsi-fungsi, masukan dan keluaran dari perangkat lunak sudah sesuai dengan spesifikasi yang dibutuhkan.

Pengujian kotak hitam dilakukan dengan membuat kasus uji yang bersifat mencoba semua fungsi dengan memakai perangkat lunak apakah sudah sesuai dengan spesifikasi yang dibutuhkan. Kasus uji yang dibutuhkan untuk melakukan pengujian kotak hitam harus dibuat dengan kasus benar dan kasus salah, misalkan kasus login maka kasus uji yang dibuat adalah [3] : 
a. Jika user memasukan nama pemakai (username) dan kata sandi (password) yang benar.

b. Jika user memasukan nama pemakai (username) dan kata sandi (password) yang salah, misalnya nama pemakai benar dan kata sandi salah, atau sebaliknya, atau keduanya salah.

\section{F. Unified Modeling Language (UML)}

UML didefinisikan sebagai bahasa visual untuk menyelesaikan, memberikan spesifikasi, merancang, membuat model dan mendokumentasikan aspek-aspek dari sebuah sistem. Berikut adalah diagram dasar dalam UML [4]:

1. Model Use Case Diagram

Use case diagram adalah pemodelan untuk menggambarkan behavior sistem yang akan dibuat. Diagram use case mendeskripsikan sebuah interaksi antara satu atau lebih aktor dengan sistem yang dapat di buat. Diagram use case juga digunakan untuk mengetahui fungsi apa saja yang ada di dalam sebuah sistem dan siapa saja yang berhak menggunakan fungsi-fungsi tersebut.

2. Model Class Diagram

Diagram class menggambarkan struktur sistem dari segi pendefinisian class-class yang dapat di buat untuk membangun sistem. Class memiliki apa yang disebut atribut dan metode atau operasi sebagai berikut :

a) Atribut merupakan variabel-variabel yang dimiliki oleh suatu class.

b) Atribut mendeskripikan properti dengan sebaris teks di dalam kotak class tersebut.

c) Operasi / metode adalah fungsi-fungsi yang dimiliki oleh suatu class.

Class diagram mendeskripsikan jenis-jenis objek dalam sistem dan berbagai hubungan statis yang terdapat di antara mereka. Class diagram juga menunjukan properti dan operasi sebuah class dan batasan-batasan yang terdapat dalam hubungan-hubungan objek tersebut.

\section{Sequence Diagram}

Diagram sequence menggambarkan behavior objek pada use case dengan mendeskripsikan waktu hidup objek dan message yang dikirimkan dan diterima antar objek. Oleh karena itu, untuk menggambarkan diagram sequence maka harus di ketahui objek-objek yang terlibat dalam sebuah use case beserta metode-metode yang dimiliki class yang diinstansiasi menjadi objek tersebut. Banyaknya diagram sequence yang harus di gambar adalah sebanyak pendefinisian use case yang memiliki proses sendiri atau semua use case yang telah didefinisikan interaksi jalannya pesan sudah dicakup pada diagram sequence.

\section{Activity Diagram}

Activity diagram menggambarkan workflow (aliran kerja) aktivitas dari sebuah sistem maupun proses bisnis. Hal yang perlu diperhatikan di sini adalah diagram aktivitas menggambarkan aktivitas sistem bukan apa yang dilakukan aktor, tetapi aktivitas yang dapat dilakukan oleh sistem.

\section{METODE PENELITIAN}

Berikut ini penulis menguraikan metode penelitian digunakan dalam melakukan penelitian ini yaitu :

A. Teknik Pengumpulan Data

1. Observasi

Pengamatan terhadap alur proses yang sedang berjalan pada CV. Anak Teladan untuk memperoleh informasi yang nantinya akan diolah kedalam sistem informasi persediaan barang.

2. Wawancara

Kegiatan wawancara dilakukan dengan admin CV. Anak Teladan, beserta pihak-pihak yang terlibat dengan kegiatan penelitian di CV. Anak Teladan.Untuk melengkapi data agar lebih valid penulis juga melakukan tanya jawab kepada saudari Dzatun Nitaqien S,Kom selaku bagian Administrasi terkait dengan proses pengolahan Stok Barang.

3. Studi pustaka

Agar data sesuai dengan teori, maka penulis juga melakukan studi pustaka dan litelatur.

B. Model Pengembangan Sistem

Metode pengembangan sistem yang digunakan dalam penelitian ini adalah dengan menggunakan model pengembangan secara Prototype. Dalam metode Prototype terdiri dari beberapa tahapan, yaitu :

1) Analisa Kebutuhan sistem

2) Desain

3) Code Generator

4) Testing

5) Support

\section{HASIL DAN PEMBAHASAN}

\section{A. Analisa Sistem Berjalan}

Berdasarkan hasil wawancara yang telah dilakukan kepada Admin, sistem yang berjalan yaitu adanya permintaan barang dari perusahaan kepada supplier dengan sistem PO (Pre Order) kemudian Supplier datang dengan barang yang sudah di pesan oleh perusahaan dan membawa surat jalan yang nanti nya diberikan kepada kepala gudang, kemudian dilakukan pengecekan barang apakah sudah sesuai dengan surat jalan yang dibawa oleh supplier. Apabila sudah sesuai, kepala gudang menandatangani surat jalan rangkap tiga yang dibawa oleh supplier. Untuk prosedur barang keluar yaitu konsumen melakukan transaksi pembelian barang, kemudian bagian admin mengkonfirmasi ke bagian gudang untuk ketersediaan barang yang dipesan oleh konsumen. Apabila barang yang dipesan konsumen tersedia, bagian gudang akan menyiapkan pesanan sesuai dengan kwitansi atau faktur pembelian. 


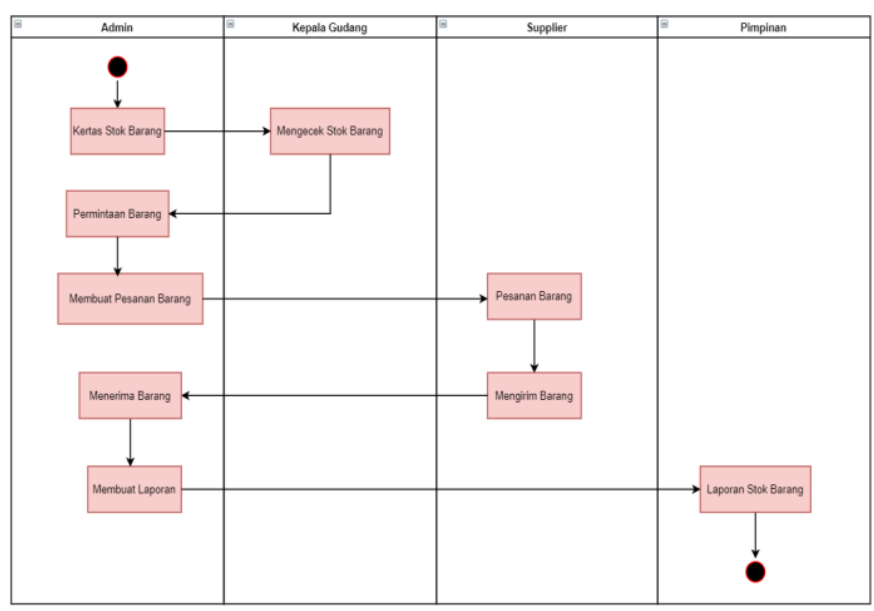

Gbr 2. Activity Diagram

\section{B. Rancangan Sistem Usulan}

Untuk membuat aplikasi yang dapat mengatasi permasalahan yang ada, maka langkah pertama yang harus dilakukan adalah mengidentifikasi kebutuhan user yang akan menggunakan program ini nanti nya. Sehingga akan mempermudah bagi penulis dalam pembuatan sistem informasi sesuai kebutuhan user.

Halaman Bagian Administrasi :

A.1. Bagian Admin dapat melakukan login untuk dapat mengakses sistem.

A.2. Bagian Admin dapat melihat dashboard.

A.3. Bagian Admin dapat mengelola data barang masuk.

A.4. Bagian Admin dapat mengelola data barang keluar.

A.5. Bagian Administrasi dapat mencetak laporan stok barang.

A.6. Bagian Administrasi dapat melakukan pengolahan pengguna.

A.7. Bagian Administrasi dapat melakukan logout.

1. Use Case Diagram

Use case diagram dibuat untuk menggambarkan perilaku dan mendeskripsikan interaksi antara satu atau lebih aktor dengan sistem informasi yang telah dibuat. Use case diagram sistem informasi Persediaan Barang pada CV. Anak Teladan dapat dilihat pada gambar 3 .

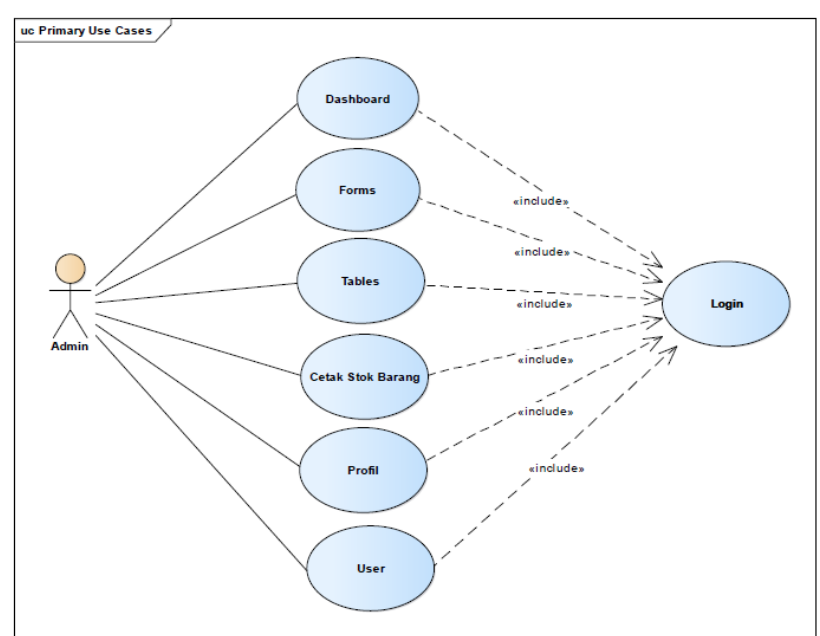

Gbr 3. Usecase diagram Halaman Admin

2. Activity Diagram

Activity diagram merupakan salah satu diagram yang ada di UML, activity diagram berfungsi untuk mendeskripsikan suatu aktivitas yang dikerjakan mulai dari awal sampai tahap terakhir.

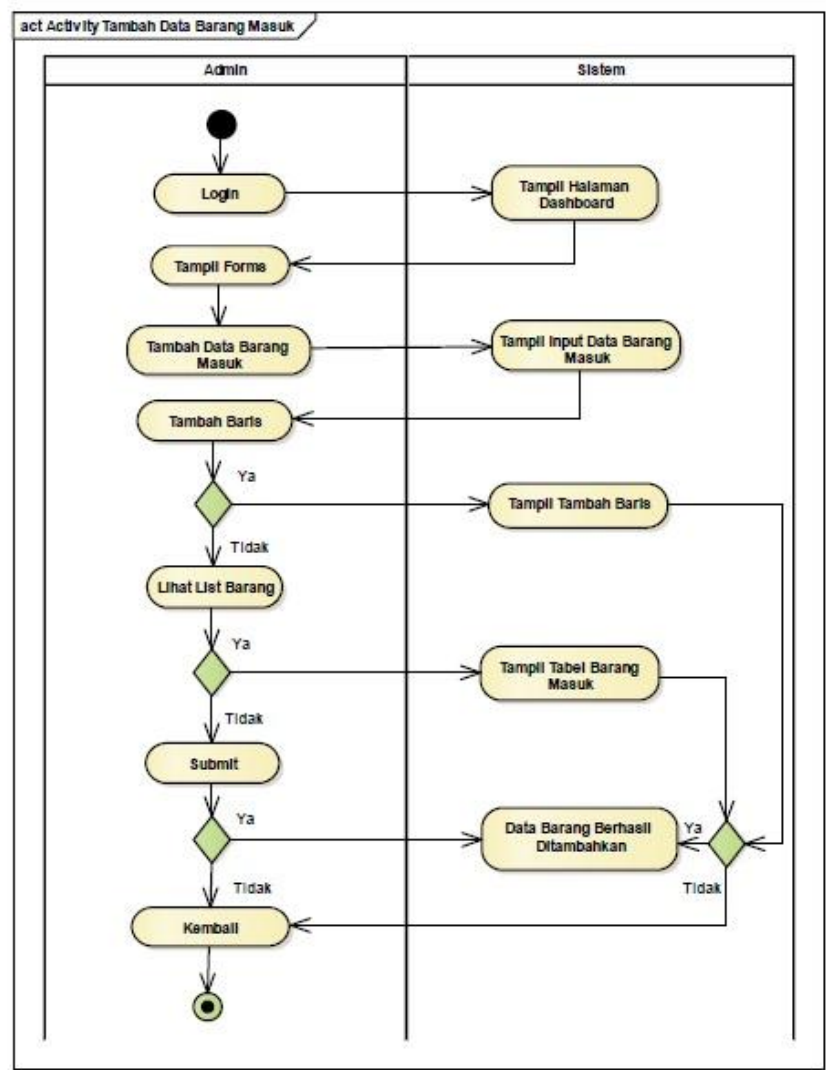

Gbr 4. Activity Diagram Tabel Barang Masuk 


\section{JURNAL SISTEM INFORMASI}

STMIK ANTAR BANGSA [VOL.X NO.1 - FEBRUARI 2021]

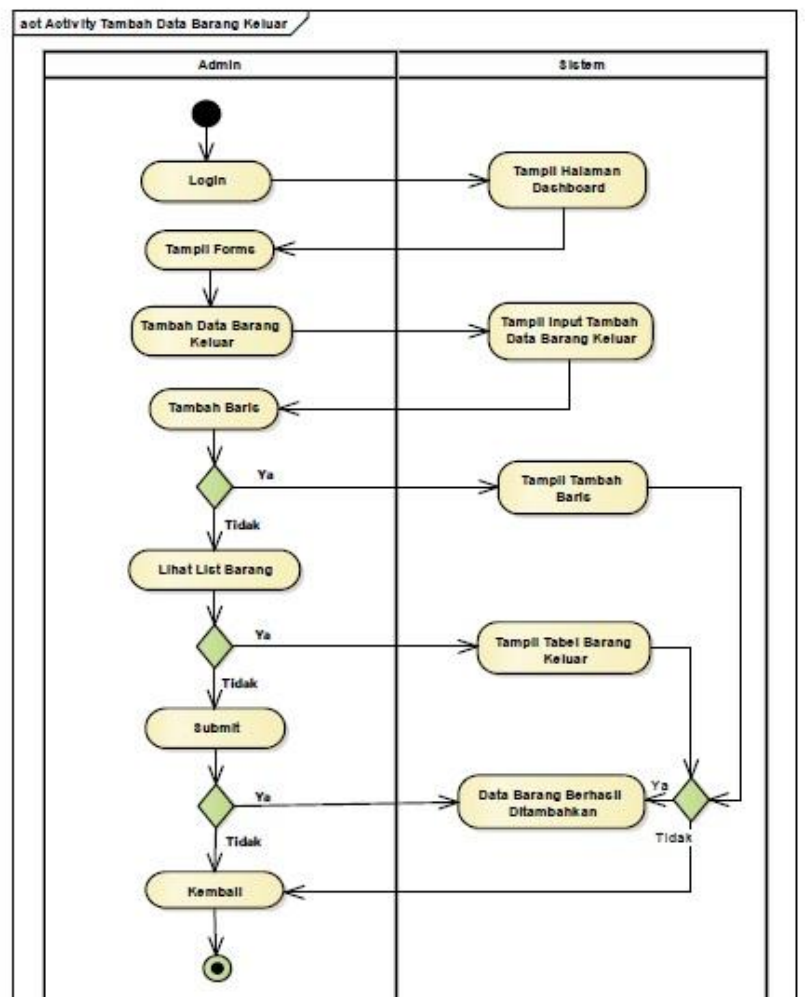

Gbr 5. Activity Diagram Tabel Barang Keluar

3. Desain

Pada tahapan ini akan di jelaskan tentang desain database, desain software architecture dan desain interface dari sistem yang dibuat. Perancangan basis data menghasilkan pemetaan tabel-tabel yang terdiri dari : tabel user, tb_upload_users, tb_list_barang_masuk, tb_list_barang_keluar, tb_master_ barang, tb_barang_masuk, tb_barang_keluar.

a. Class Diagram

Class diagram mendeskripsikan jenis-jenis objek dalam sistem dan berbagai hubungan statis yang terdapat di antara mereka. Class diagram juga menunjukan properti dan operasi sebuah class dan batasan-batasan yang terdapat dalam hubungan-hubungan objek tersebut.

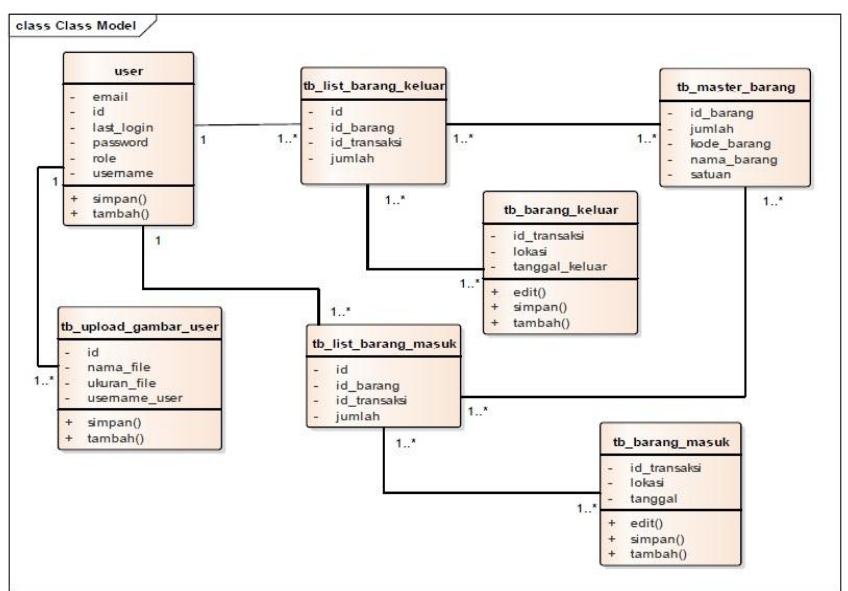

Gbr 6. Class Diagram

b. Sequence Diagram

Diagram squence menggambarkan interaksi antar objek pada usecase dengan mendeskripsikan waktu hidup objek dan pesan yang dikirimkan dan diterima antar objek. Oleh karena itu, untuk menggambar diagram squnece maka harus di ketahui obejk-objek yang terlibat dalam sebuah usecase beserta metode-metode yang dimiliki class yang diinstansiasi menjadiobjek itu.

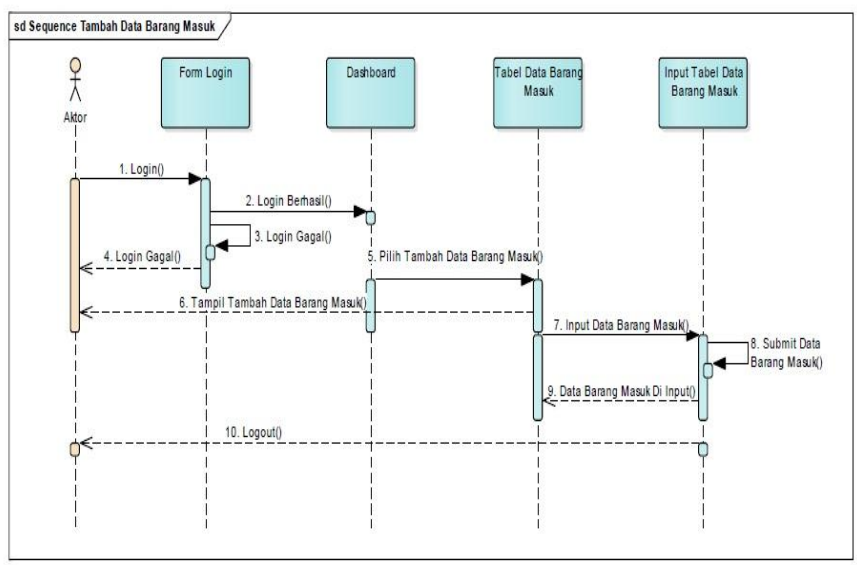

Gbr 7. Sequence Diagram Tambah Data Barang Masuk

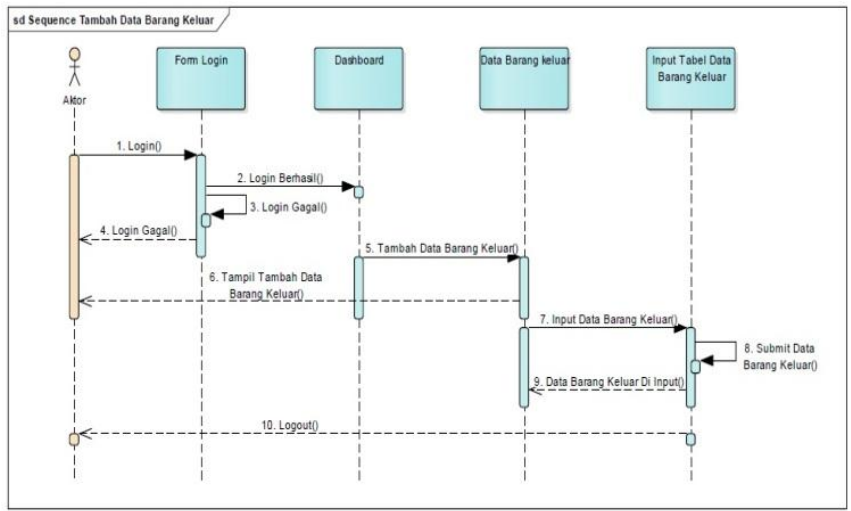

Gbr 8. Sequence Diagram Tambah Data Barang Masuk 
c. Deployment Diagram

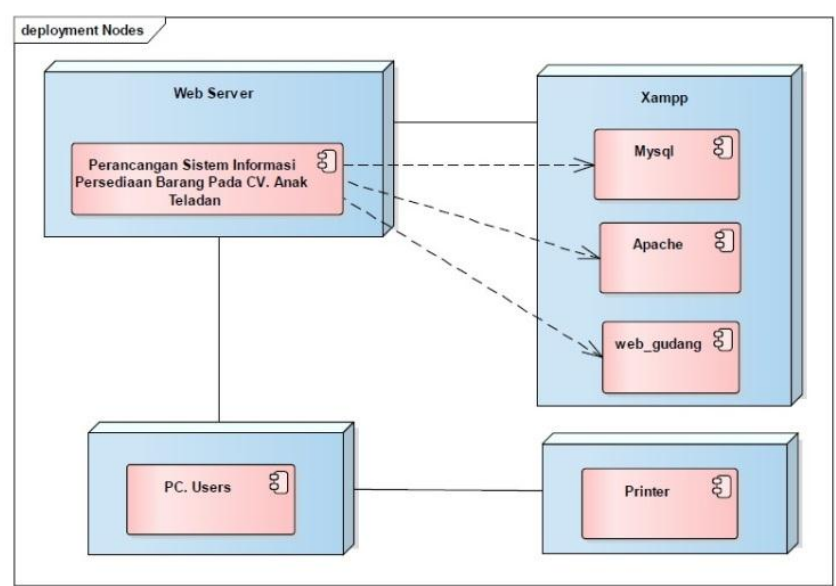

Gbr 9. Deployment Diagram

d. Component Diagram

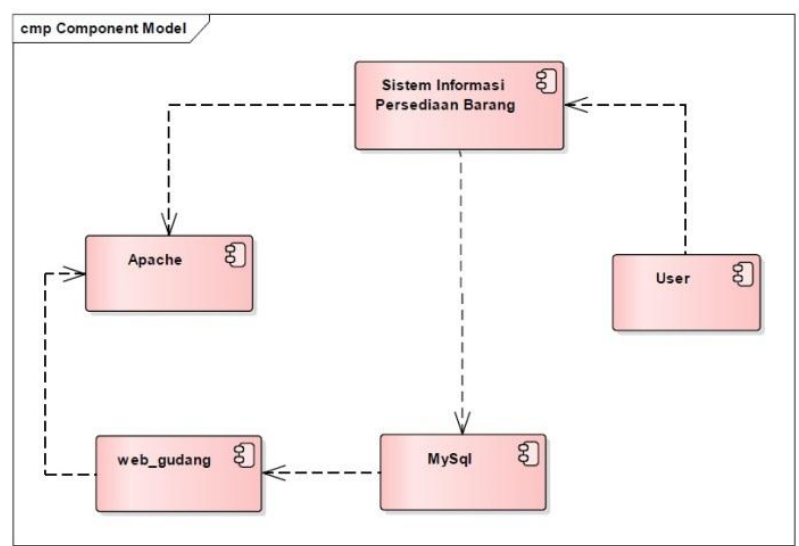

Gbr 10. Component Diagram

e. User Interface

Desain antar muka ini sangat diperlukan untuk memberikan informasi dari pembahasan dan program yang dibuat oleh penulis. Berikut tampilan antar muka yang penulis sajikan :

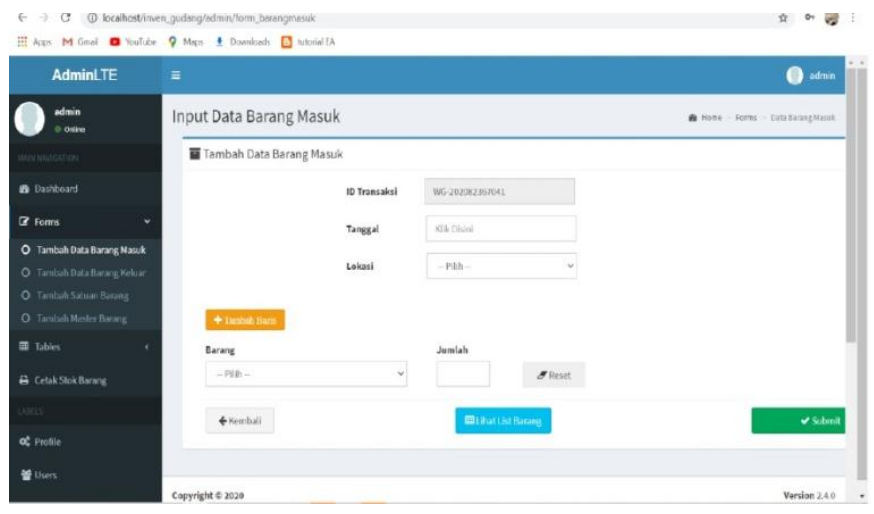

Gbr.11 Input Data Barang Masuk

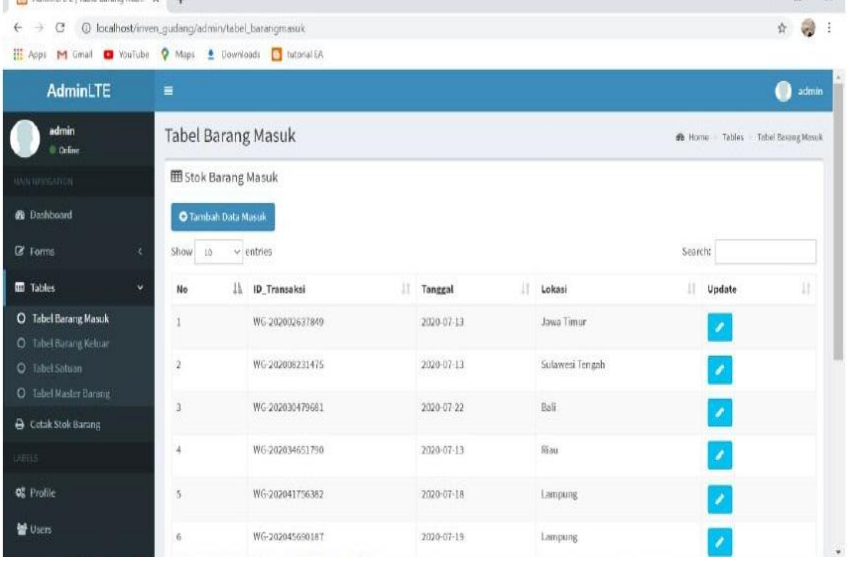

Gbr 12. Menu Tabel Barang Keluar

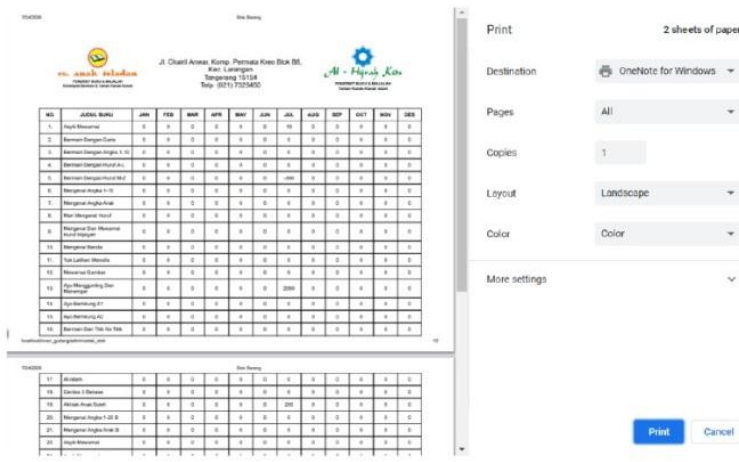

Gbr 13. Menu Cetak Stok Barang

TABEL 1

TESTING FORM DATA BARANG MASUK

\begin{tabular}{|c|c|c|c|c|c|}
\hline No. & $\begin{array}{l}\text { Skenario } \\
\text { Pengujian }\end{array}$ & Test Case & $\begin{array}{c}\text { Hasil } \\
\text { yang } \\
\text { Diharap } \\
\text { kan }\end{array}$ & $\begin{array}{c}\text { Hasil } \\
\text { Pengujian }\end{array}$ & $\begin{array}{l}\text { Kesim } \\
\text { pulan }\end{array}$ \\
\hline 1 & $\begin{array}{l}\text { Mengo } \\
\text { sosngkan } \\
\text { semua } \\
\text { isian } \\
\text { form input, } \\
\text { lalu } \\
\text { klik } \\
\text { simpan }\end{array}$ & $\begin{array}{l}\text { Tanggal : } \\
\text { (kosong) } \\
\text { Lokasi : } \\
\text { (kosong) } \\
\text { Pilih } \\
\text { Barang : } \\
\text { (kosong) } \\
\text { Jumlah : } \\
\text { (kosong) }\end{array}$ & $\begin{array}{l}\text { Sistem } \\
\text { akan } \\
\text { menolak } \\
\text { akses }\end{array}$ & $\begin{array}{l}\text { login } \\
\text { Sesuai } \\
\text { harapan }\end{array}$ & Valid \\
\hline 2 & $\begin{array}{l}\text { Mengisi } \\
\text { beberapa } \\
\text { isian } \\
\text { form input, } \\
\text { lalu } \\
\text { klik } \\
\text { simpan }\end{array}$ & $\begin{array}{l}\text { Tanggal : } \\
\text { (kosong) } \\
\text { Lokasi : } \\
\text { Lampung) } \\
\text { Pilih } \\
\text { Barang : } \\
\text { (kosong) } \\
\text { Jumlah : } \\
\text { (kosong) }\end{array}$ & $\begin{array}{l}\text { Sistem } \\
\text { akan } \\
\text { menolak } \\
\text { akses }\end{array}$ & $\begin{array}{l}\text { login } \\
\text { Sesuai } \\
\text { harapan }\end{array}$ & Valid \\
\hline 3 & $\begin{array}{l}\text { Mengisi } \\
\text { semua } \\
\text { form input }\end{array}$ & $\begin{array}{l}\text { Tanggal : } \\
(22-07- \\
2020)\end{array}$ & $\begin{array}{l}\text { Sistem } \\
\text { akan } \\
\text { menolak }\end{array}$ & $\begin{array}{l}\text { login } \\
\text { Sesuai } \\
\text { harapan }\end{array}$ & Valid \\
\hline
\end{tabular}




\begin{tabular}{|l|l|l|l|l|l|}
\hline $\begin{array}{l}\text { barang, } \\
\text { lalu klik } \\
\text { simpan }\end{array}$ & $\begin{array}{l}\text { Lokasi : } \\
\text { (Lampung }\end{array}$ & akses & & \\
& Pilih & & & \\
& $\begin{array}{l}\text { Barang: } \\
\text { (Asyik } \\
\text { Membaca) }\end{array}$ & & & \\
& & & & \\
& & & & \\
& & & & \\
\hline
\end{tabular}

\section{KESIMPULAN}

Berdasarkan hasil dari analisa diatas maka penulis dapat mengambil kesimpulan sebagai berikut :

1. Selama ini CV. Anak Teladan masih menggunakan sistem manual, dengan menggunakan kertas untuk menyimpan data stok barang sehingga kurang efektif karena sering terjadinya data rusak, hilang atau sebagainya. sehingga memperlambat dalam pembuatan laporan stok barang. Dengan mengunakan sistem diharapkan dapat mencegah keterlambatan dalam pembuatan laporan stok barang.

2. Dirancangnya sistem informasi persediaan barang pada CV. Anak Teladan untuk mempermudah bagian gudang memberikan laporan kepada pimpinan.

3. Aplikasi sistem pengolahan data juga dapat digunakan untuk membantu meminimalkan tingkat kesalahan yang biasanya terjadi dalam sistem manual.

\section{REFERENSI}

[1] Abdul Kadir, Pengenalan Sistem Informasi Edisi Revisi, Revisi. Yogyakarta: cv. ANDI OFFSET, 2014.

[2] Tata Sutabri, Analisis Sistem Informasi. Jakarta: ANDI OFFSET, 2012.

[3] M. Shalahuddin, Rekayasa Perangkat Lunak. Bandung: Informatika Bandung, 2016.

[4] M. K. Yunu Sugiarti, S.T., Dasar-Dasar Pemrograman Java Netbeans; Database, UML dan Interface. Bandung: PT Remaja Rosdakarya, 2018.

[5] K. Setiawan, Herlawati, and E. Retnoningsih, "Sistem Informasi Persediaan , Pembelian dan Penjualan Barang Pada CV Evee Store Cileungsi,” J. Mhs. Bina Insa., vol. 2, no. 1, pp. 25-36, 2017.

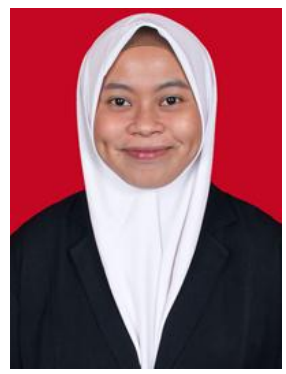

Fenny Hidha Rahmawati. Lahir di Jombang, pada Tanggal 16 April 1994. Tahun 2020 lulus dari Program Strata Satu (S1) Jurusan Sistem Informasi di STMIK Antar Bangsa.

$$
\text { Antar Bangsa. }
$$

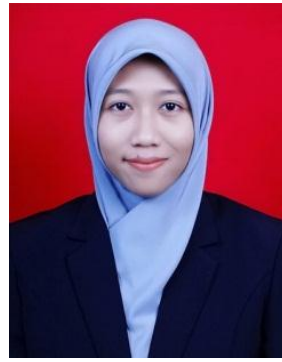

Esthi Adityarini. Lahir di Jakarta, pada Tanggal 31 Januari 1994. Tahun 2015 lulus dari Program Strata Satu (S1) Jurusan Teknik Informatika di STMIK Antar Bangsa. Tahun 2020 lulus dari Program Pascasarjana (S2) Konsentrasi Teknologi Sistem Informasi pada Jurusan Ilmu Komputer di Universitas Budi Luhur. Saat ini aktif mengajar dan juga sebagai operator PDDIKTI di Institut Daarul Qur'an. 